\title{
ANALISIS FAKTOR-FAKTOR YANG BERPENGARUH TERHADAP NIAT BERWIRAUSAHA MAHASISWA
}

\author{
Afriyanti Hasanah ${ }^{1)}$ Nurhasikin ${ }^{2)}$ \\ 1) 2)Jurusan Manajemen Bisnis, Politeknik Negeri Batam \\ Jl. Ahmad Yani, Batam Center, Batam 29461, Indonesia \\ E-mail: Nurhasikinns@gmail.com, Afriyanti@polibatam.ac.id
}

\begin{abstract}
This study aims to analyze the factors that influence student entrepreneurship intentions. This study uses 260 respondents taken from the students of Business Management Department at Politeknik Negeri Batam who have received entrepreneurial courses. The type of data used in this study is the interval scale, while the scaling method used in the form of likert scale instrument with 4 assessment categories. Data analysis techniques in this study used multiple regression analysis. The results of this study indicate that there are influences of parents' job, entrepreneurial experience, self efficacy, entrepreneurship education, academic support and social support on student entrepreneurial intentions, while gender and environment support do not affect student entrepreneurial intentions. Future studies are expected to increase the number of research samples, change research samples or add research variables.
\end{abstract}

Keywords: Gender, parent's job, business experience, self efficacy, entrepreneurship education, academic support, social support, environment support, entrepreneurship intention

\begin{abstract}
Abstrak
Penelitian ini bertujuan untuk menganalisis pengaruh faktor-faktor niat berwirsausaha mahasiswa. Penelitian ini menggunakan 260 responden yang diambil dari mahasiswa Manajemen Bisnis Politeknik Negeri Batam yang telah mendapatkan matakuliah kewirausahaan. Jenis data yang digunakan pada penelitian ini berupa skala interval, sedangkan metode penskalaan yang digunakan pada instrument berupa skala likert dengan 4 kategori penilaian. Teknik analisis data dalam penelitian ini menggunakan analisis regresi berganda. Hasil penelitian ini menunjukkan bahwa terdapat pengaruh dari pekerjaan orang tua, pengalaman berwirausaha, efikasi diri, pendidikan kewirausahaan, academic support dan social support terhadap niat berwirausaha mahasiswa, sedangkan gender dan environment support tidak mempengaruhi niat berwirausaha mahasiswa. Penelitian selanjutnya diharapkan dapat menambah jumlah sampel penelitian, merubah sampel penelitian atau menambah variabel penelitian.
\end{abstract}

Kata Kunci: Gender, pekerjaan orang tua, pengalaman usaha, efikasi diri, pendidikan kewirausahaan, academic support, social support, environment support, Niat berwirausaha 


\section{PENDAHULUAN}

Tingkat pengangguran di Kepulauan Riau semakin meningkat jumlahnya, seiring dengan tingkat persaingan yang semakin ketat untuk mendapatkan pekerjaan dengan kondisi lapangan pekerjaan yang sangat terbatas. Berdasarkan berita yang dilansir di BatamPos.co.id (13/11/2017) melalui data yang diperoleh dari Badan Pusat Statistik (BPS) menyebutkan angkatan kerja di Provinsi Kepulauan Riau pada Agustus 2017 sebanyak 966,091 orang. Sementara penduduk yang sudah bekerja sebanyak 896,931 orang, artinya sebanyak 69,160 orang lagi yang masih belum memiliki pekerjaan. Berdasarkan berita yang dilansir dari laman TribunBatam.com (29/5/2017) dikatakan sejak Januari sampai Mei 2017 lalu terdapat 34 perusahaan di Batam tidak lagi beroperasi diakibatkan perekonomian menurun drastis, sehingga perusahaan melakukan Pemutusan Hubungan Kerja kepada ribuan karyawan dan menyebabkan jumlah pengangguran semakin bertambah.

Melihat situasi ini maka lulusan dari perguruan tinggi diharapkan dapat menciptakan lapangan pekerjaan. Menjadi wirausaha adalah salah satu cara untuk meminimalkan jumlah pencari kerja dan pengangguran dengan kondisi kota Batam yang sedang kurang ketersediaan lapangan pekerjaan. Menumbuhkan minat berwirausaha para mahasiswa perguruan tinggi dipercaya menjadi alternatif untuk mengurangi tingkat pengangguran, karena para sarjana diharapkan dapat menjadi wirausaha muda terdidik yang mampu merintis usahanya sendiri. Zimmerer (2002) menyatakan bahwa salah satu faktor pendorong pertumbuhan wirausaha di suatu negara terletak pada peranan Perguruan Tinggi melalui penyelenggaraan pendidikan kewirausahaan. Salah satu Perguruan Tinggi di Batam yang mendorong mahasiswa untuk berwirausaha ialah Politeknik Negeri Batam, dengan menambahkan mata kuliah kewirausahaan pada beberapa program studi.

Penelitian ini dilatarbelakangi oleh beberapa penelitian sebelumnya yang menyatakan bahwa, faktor-faktor yang mempengaruhi niat mahasiswa berwirausaha bukan hanya mata kuliah kewirausahaan, namun ada beberapa faktor lain yang mempengaruhi hal tersebut. Suharti et al (2011) menjelaskan bahwa beberapa faktor pendorong niat mahasiswa untuk berwirausaha yakni faktor internal yang berasal dari diri seseorang seperti sikap dan juga sosio demografi yang berkaitan dengan jenis kelamin, pengalaman berwirausaha, latar belakang keluarga dan lain-lain, sedangkan faktor eksternal berasal dari luar diri seseorang seperti lingkungan sekitar dan kondisi kontekstual. Sampel yang digunakan adalah mahasiswa eksakta dan non eksakta karena di dalam faktor sosio demografi peneliti terdahulu ingin menduga apakah terdapat pengaruh bidang studi terhadap niat berwirausaha. Rachmawan et al (2015) menyatakan faktor internal seperti efikasi diri juga terbukti mempengaruhi niat berwirausaha mahasiswa melalui penelitiannya di Institut Pertanian Bogor. Zulianto et al (2014) lebih dulu mengungkapkan bahwa efikasi diri dan faktor kontekstual yakni Pendidikan kewirausahaan berpengaruh terhadap minat berwirausaha mahasiswa. Sampel yang digunakan ialah mahasiswa Pendidikan Tata 
Niaga yang sudah mendapatkan mata kuliah kewirausahaan.

Perbedaan penelitian ini dengan penelitian terdahulu adalah penelitian ini akan dilakukan di Politeknik Negeri Batam dengan mengambil sampel mahasiswa Manajemen Bisnis yang sudah mendapatkan mata kuliah kewirausahaan. Penelitian ini tidak melakukan perbandingan antar bidang studi seperti penelitian yang dilakukan oleh Suharti et al (2011) karena fokus penelitian ini di Jurusan Manajemen Bisnis yang lebih dominan mempelajari hal terkait kewirausahaan. Variabel yang diteliti oleh Suharti et al (2011) adalah faktor sosio demografi, faktor sikap dan faktor

kontekstual terhadap niat berwirausaha, Rachmawan et al (2015) meneliti variabel efikasi diri terhadap niat berwirausaha, Zulianto et al (2014) meneliti tentang variabel efikasi diri dan Pendidikan kewirausahaan terhadap minat berwirausaha. Variabel yang akan diteliti pada penelitian ini adalah variabel faktor sosio demografi, faktor efikasi diri dan faktor kontekstual terhadap niat berwirausaha mahasiswa. Penelitian ini tidak menggunakan variabel sikap karena variabel efikasi diri sudah mewakili variabel sikap melalui pertanyaan yang diajukan.

\section{LANDASAN TEORI}

Teori yang peneliti gunakan dalam penelitian ini adalah teori wirausaha, teori niat berwirausaha dan teori faktor-faktor memotivasi niat berwirausaha.

\section{Teori Wirausaha}

Wirausaha adalah orang yang dapat mengusahakan pekerjaan untuk dirinya sendiri maupun untuk orang lain, melalui pengetahuan dan bakat yang dimiliki dalam mengenali dan menciptakan produk baru, memasarkan dan mengelola permodalan operasinya. Wirausaha ialah pengusaha sukses karena memiliki ciri-ciri serta kemampuan tertentu dalam menciptakan sesuatu yang baru (Subanar, 2001).

\section{Teori Niat Berwirausaha}

Alma (2001) menyatakan berwirausaha adalah kegiatan untuk melakukan suatu usaha berdasarkan ide-ide kreatif dan inovatif dengan karakteristik kepribadian yang berani menghadapi tantangan, percaya diri, siap mental, berorientasi ke masa depan dan mempunyai keterampilan untuk memenuhi kebutuhan. Menurut Suryaman (2006) niat berwirausaha adalah suatu kemampuan untuk memberanikan diri dalam memenuhi kebutuhan hidup serta memecahkan permasalahan hidup, memajukan usaha atau menciptakan usaha baru dengan kemampuan yang ada pada diri sendiri.

Pada dasarnya pembentukan jiwa berwirausaha dipengaruhi oleh faktor internal dan eksternal (Priyanto, 2008). Faktor internal yang berasal dari dalam diri wirausahaaan dapat berupa sifat-sifat personal, sikap, kemauan, motivasi atau kemampuan individu yang dapat memberi kekuatan individu untuk berwirausaha. Sedangkan faktor eksternal berasal dari luar diri pelaku wirausaha yang dapat berupa unsur dari lingkungan sekitar seperti lingkungan keluarga, lingkungan dunia usaha, lingkungan fisik, lingkungan sosial ekonomi dan lain-lain. 
Journal of Business Administration Vol 3, No 2, September 2019, hlm, 194-204

\section{Teori faktor-faktor memotivasi niat berwirausaha}

Sejumlah penelitian yang telah dilakukan terhadap motivasi seseorang untuk berwirausaha, dapat dikatakan bahwa niat berwirausaha seseorang dipengaruhi sejumlah faktor yang dapat dilihat dalam suatu kerangka integral yang melibatkan berbagai faktor internal, faktor eksternal dan faktor kontekstual (Johnson, 1990 ; Stewart et al., 1998)

Faktor internal ialah faktor yang berasal dari dalam diri seorang wirausaha seperti karakter sifat maupun faktor sosio demogarafi seperti jenis kelamin, umur, latar belakang keluarga, pengalaman berwirausaha dan lain-lain yang dapat mempengaruhi niat seseorang berwirausaha (Johnson, 1990; Nishanta, 2008). Faktor internal lainnya ialah efikasi diri, Bandura (1997) mendefinisikan efikasi diri sebagai kemampuan untuk mengatur dan melaksanakan tindakan yang dibutuhkan untuk menghasilkan pencapaian yang diinginkan. Efikasi diri diperlukan sebab berkaitan erat dengan kepercayaan diri individu pada kemampuan yang dimilikinya untuk memberikan kontrol agar setiap kejadian yang akan mempengaruhi hidupnya.

\section{METODE PENELITIAN}

Sampel dari penelitian ini adalah mahasiswa Manajemen Bisnis Politeknik Negeri Batam. Metode yang digunakan dalam penelitian ini menggunakan uji statistik deskriptif, uji reliabilitas, uji validitas, uji asumsi klasik, analisis regresi berganda dan uji T-test. Model analisis regresi berganda dipilih untuk mengetahui pengaruh antara variabel dependen dan variabel independen.

\section{Variabel Bebas (Independent)}

Variabel bebas termasuk variabel yang mempengaruhi, yang menyebabkan timbulnya atau berubah variabel terikat (Sugiyono,2010). Variabel bebas yang digunakan pada penelitian ini ialah faktor sosiodemografi (gender, pekerjaan orang tua, pengalaman berwirausaha), faktor efikasi diri dan faktor kontekstual (pendidikan kewirausahaan, academic support, social support dan environment support.

\section{Variabel Terikat (Dependent)}

Variabel terikat adalah variabel yang dipengaruhi karena adanya variabel bebas (Sugiyono, 2010). Variabel terikat yang digunakan dalam penelitian ini adalah niat berwirausaha mahasiswa.

\section{Teknik Penarikan Sampel}

Penelitian ini peneliti menggunakan metode purposive sampling yang merupakan bagian dari pengambilan sampel secara non random (non probability).

\section{Teknik Pengumpulan Data}

Teknik pengumpulan data menggunakan koesioner yang akan dibagikan kepada mahasiswa manajemen bisnis Politeknik Negeri Batam. Koesioner yang akan disebar terdiri dari rangkaian pernyataan yang berkaitan dengan penelitian peneliti.

\section{Teknik Pengolahan Data}

Teknik pengolahan data dalam penelitian ini menggunakan program SPSS 22, 
Afriyanti Hasanah \& Nurhasikin, Analisis Faktor-Faktor yang Berpengaruh Terhadap...

Kuesioner yang telah terisi, akan diuji validitas dan reliabilitasnya. Uji validitas dilakukan menggunakan korelasi pearson sedangkan uji reliabilitas dilakukan dengan menggunakan uji statistik alpha-cronbach. Pernyataan kuesioner dinyatakan valid apabila nilai $\mathrm{r}$ hitung > $\mathrm{r}$ tabel (Ghozali, 2012).

\section{Teknik Analisis Data}

Teknik analisis data dalam penelitian ini menggunakan analisis regresi berganda. Analisis regresi berganda dilakukan untuk membuktikan hasil hipotesis yang telah diajukan apakah terdukung atau tidak. Menurut Sugiyono (2010), untuk dapat melakukan analisis regresi linier berganda diperlukan pengujian statistic diskriptif, uji asumsi klasik dan uji hipotesis.

\section{Uji Analisis Regresi}

Pengujian ini menggunakan uji-t statistik untuk mengetahui pengaruh antara variabel independen (gender, pekerjaan orang tua, pengalaman berwirausaha, efikasi diri, Pendidikan kewirausahaan, academic support, social support, environment support). Analisis data dari penelitian ini menggunakan model regresi linier berganda. Persamaan analisis regresi linier berganda dengan model penelitian ini adalah:

\section{$\mathbf{Y}=a+\mathbf{b}_{4} \mathbf{E D}+\mathrm{b}_{5} \mathrm{PK}+\mathrm{b}_{6} \mathrm{AS}+\mathrm{b}_{7} \mathrm{SS}+\mathrm{b}_{8} \mathrm{ES}+\mathrm{e}$}

Dimana Y merupakan variabel dependen (niat berwirausaha), $\alpha$ merupakan nilai konstanta, b4-b8 merupakan koefisien regresi, ED (efikasi diri), PK (Pendidikan kewirausahaan), AS (academic support), SS (social support), ES (environment support) dan e standar error.

\section{Uji-t (parsial)}

Uji $\mathrm{t}$ digunakan untuk menguji secara parsial dari masing-masingvariabel $\mathrm{X}_{4}$ sampai dengan $\mathrm{X}_{8}$. Hasil uji $\mathrm{t}$ dapat dilihat pada tabel coefficient di kolom sig(significance) dengan kriteriasebagai berikut (Ghozali, 2012):

a. Jika signifikansi $>0.05$ atau $\mathrm{t}$ hitung $<\mathrm{t}$ tabel maka $\mathrm{H} 0$ diterima danHa

ditolak.

b. Jika signifikansi $<0.05$ atau $\mathrm{t}$ hitung $>\mathrm{t}$ tabel maka H0 ditolak danHa diterima.

\section{Uji beda (independent sampel t-test)}

Independen sampel t-test digunakan untuk menentukan apakah dua sampel yang tidak berhubungan memiliki nilai rata-rata yang berbeda (Ghozali, 2011). Terdapat dua jenis uji beda t-test yaitu two tailed (jika hubungan kedua variabel belum diketahui) dan one tailed (jika hubungan kedua variabel sudah diketahui kecendrungannya berhubungan positif atau negatif). Uji beda digunakan untuk mengukur variabel dari $\mathrm{X}_{1}$ (Gender), $\mathrm{X}_{2}$ (Pekerjaan orang tua) dan $\mathrm{X}_{3}$ (Pengalaman berwirausaha) dengan Pengambilan keputusan didasarkan perbandingan nilai probabilitas yang dihasilkan model uji dengan nilai tingkat kepercayaan sebesar 0,05 . 
Journal of Business Administration Vol 3, No 2, September 2019, hlm, 194-204

HASIL DAN PEMBAHASAN

\section{Statistik Deskriptif}

Tabel 1. Statistik Deskriptif

\begin{tabular}{lccccc}
\hline Variabel & & & & & $\begin{array}{c}\text { Standar } \\
\text { N }\end{array}$ \\
\hline Efikasi diri & 260 & 30 & 50 & 40,50 & 6,050 \\
Pendidikan Kewirausahaan & 260 & 30 & 50 & 40,58 & 6,048 \\
Acodemic Support & 260 & 6 & 16 & 10,81 & 2,089 \\
Social Support & 260 & 3 & 12 & 8,92 & 1,380 \\
Environment Support & 260 & 4 & 16 & 9,84 & 3,847 \\
Niat Berwirausaha & 260 & 3 & 12 & 7,48 & 2,788 \\
& & & & & \\
\hline Sumber: Data diolah menggunakan SPSS & & & &
\end{tabular}

Tabel 2. Rangkuman Hasil Uji Hipotesis

\begin{tabular}{|c|c|c|}
\hline Hipotesis & Signifikansi & Hasil \\
\hline $\begin{array}{l}\text { H1: Terdapat perbedaan niat } \\
\text { berwirausaha mahasiswa berdasarkan } \\
\text { gender }\end{array}$ & 0,926 & Tidak Terdukung \\
\hline $\begin{array}{l}\mathrm{H} 2: \text { Terdapat perbedaan niat } \\
\text { berwirausaha mahasiswa berdasarkan } \\
\text { pekerjaan orang tua }\end{array}$ & 0,019 & Terdukung \\
\hline $\begin{array}{l}\text { H3: Terdapat perbedaan niat } \\
\text { berwirausaha mahasiswa berdasarkan } \\
\text { pengalaman berwirausaha }\end{array}$ & 0,030 & Terdukung \\
\hline $\begin{array}{l}\text { H4: Efikasi diri berpengaruh terhadap } \\
\text { niat berwirausaha mahasiswa }\end{array}$ & 0,040 & Terdukung \\
\hline $\begin{array}{l}\text { H5: Pendidikan kewirausahaan } \\
\text { berpengaruh terhadap niat } \\
\text { berwirausaha mahasiswa }\end{array}$ & 0,026 & Terdukung \\
\hline $\begin{array}{l}\text { H6: Acodemic support berpengaruh } \\
\text { terhadap niat berwirausaha } \\
\text { mahasiswa }\end{array}$ & 0,010 & Terdukung \\
\hline Hipotesis & Signifikansi & Hasil \\
\hline $\begin{array}{lll}\text { H7: Social } & \text { support } & \text { berpengaruh } \\
\text { terhadap } & \text { niat } & \text { berwirausaha } \\
\text { mahasiswa } & & \end{array}$ & 0,047 & Terdukung \\
\hline $\begin{array}{l}\text { H8: Environment support berpengaruh } \\
\text { terhadap niat berwirausaha } \\
\text { mahasiswa. }\end{array}$ & 0,591 & Tidak Terdukung \\
\hline
\end{tabular}

\section{Terdapat Perbedaan Niat Berwirausaha}

\section{Mahasiswa Berdasarkan Gender}

Berdasarkan hasil uji statistik pada tabel 2 diatas menunjukkan bahwa tidak terdapat perbedaan niat berwirausaha mahasiswa berdasarkan gender. Tidak terdapat adanya perbedaan niat berwirausaha dikarenakan mahasiswa manajemen bisnis Politeknik Negeri Batam baik laki-laki maupun perempuan sama-sama berada di lingkungan yang dominan mempelajari dunia bisnis dan juga telah mendapatkan matakuliah kewirausahaan, sehingga mereka memiliki pandangan yang sama mengenai keuntungan dan kelebihan yang akan didapatkan ketika mereka berwirausaha.

Hasil penelitian ini mendukung penelitian dari Suharti (2011) dan Yunilasari (2016) yang menyatakan bahwa faktor jenis kelamin tidak berpengaruh terhadap niat berwirausaha mahasiswa. Maka dari itu dapat dikatakan bahwa jenis kelamin tidak mempengaruhi niat mahasiswa untuk berwirausaha.

\section{Terdapat Perbedaan Niat Berwirausaha Mahasiswa Berdasarkan Pekerjaan Orang Tua}

Berdasarkan hasil uji stastistik yang ditampilkan pada tabel 2 menunjukkan bahwa variabel pekerjaan orang tua terbukti memiliki perbedaan antara orang tua mahasiswa yang berwirausaha dan tidak berwirausaha. Pada umumnya seorang anak akan mengikuti jejak orang tuanya dalam karir, jika orang tua berwirausaha maka seorang anak akan termotivasi untuk berwirausaha dan biasanya dukungan orang tua lebih besar ketika seorang anak mengikuti langkah orang tua untuk berwirausaha. Sebaliknya jika orang tua tidak berwirausaha maka kecil kemungkinan anaknya untuk berwirausaha, sehingga pekerjaan orang tua menjadi salah satu pengaruh niat berwirausaha mahasiswa Politeknik Negeri Batam.

Hasil penelitian ini mendukung penelitian dari Suharti (2011) dan Yunilasari (2016) yang menyatakan bahwa mahasiswa yang 
Afriyanti Hasanah \& Nurhasikin, Analisis Faktor-Faktor yang Berpengaruh Terhadap...

memiliki orang tua yang berwirausaha memiliki niat berwirausaha lebih tinggi dibandingkan dengan mahasiswa yang orang tuanya tidak berwirausaha. oleh sebab itu dapat dikatakan bahwa terdapat perbedaan niat berwirausaha mahasiswa berdasarkan pekerjaan orang tua.

\section{Terdapat Perbedaan Niat Berwirausaha} Mahasiswa Berdasarkan Pengalaman Berwirausaha

Berdasarkan hasil uji statistik pada tabel 2, menunjukkan bahwa variabel pengalaman berwirausaha terbukti memiliki perbedaan antara mahasiswa yang pernah berwirausaha dan yang tidak berwirausaha. Pengalaman menjadi guru terbaik yang dapat membekali seseorang dengan keadaan konkrit sesuai kondisi nyata dalam kehidupan sehari-hari. Mahasiswa yang memiliki pengalaman berwirausaha akan cenderung memiliki motivasi lebih besar untuk berwirausaha dibandingkan dengan mahasiswa yang tidak mempunyai pengalaman berwirausaha.

Hasil penelitian ini mendukung penelitian dari Suharti (2011) dan Farouk (2014) yang menyatakan bahwa mahasiswa yang memiliki pengalaman berwirausaha memiliki niat berwirausaha lebih tinggi dibandingkan dengan mahasiswa yang tidak mempunyai pengalaman berwirausaha. oleh sebab itu dapat dikatakan bahwa terdapat perbedaan niat berwirausaha mahasiswa berdasarkan pengalaman berwirausaha.

\section{Efikasi Diri Berpengaruh Terhadap Niat} Berwirausaha Mahasiswa

Berdasarkan hasil uji statistik pada tabel 2, menunjukan bahwa variabel efikasi diri terbukti berpengaruh terhadap niat berwirausaha mahasiswa. Semakin tinggi kepercayaan diri seseorang atas kemampuan dirinya dalam berwirausaha, maka semakin besar pula keinginan seseorang untuk menjadi wirausaha.

Hasil penelitian ini mendukung penelitian dari Rachmawan (2015) dan Zulianto (2014) yang menyatakan bahwa efikasi diri terbukti mempengaruhi niat berwirausaha mahasiswa.

\section{Pendidikan Kewirausahaan Berpengaruh} Terhadap Niat Berwirausaha Mahasiswa

Berdasarkan hasil uji statistik pada tabel 2, menunjukan bahwa variabel pendidikan kewirausahaan terbukti berpengaruh terhadap niat berwirausaha mahasiswa. Mahasiswa yang telah mendapatkan pelajaran kewirausahaan telah mendapatkan ilmu berwirausaha yang lebih dibandingkan dengan mahasiswa yang tidak mendapatkan matakuliah kewirausahaan, sehingga mahasiswa memiliki gambaran dunia usaha setelah mempelajari kewirausahaan dan memiliki niat berwirausaha lebih tinggi.

Hasil penelitian ini mendukung penelitian dari Farouk (2014) dan Sinarasri (2012) yang menyatakan bahwa pendidikan kewirausahaan terbukti mempengaruhi niat berwirausaha mahasiswa.

\section{Academic Support Berpengaruh Terhadap Niat Berwirausaha Mahasiswa}

Berdasarkan hasil uji statistik pada tabel 2, meunjukkan bahwa variabel academic support terbukti berpengaruh terhadap niat berwirausaha mahasiswa. Mahasiswa yang merasa pihak perguruan tinggi mendorong dan memberikan kemudahan fasilitas untuk mahasiswa berlatih berwirausaha di kampus akan memberikan motivasi yang besar kepada mahasiswa untuk membuka usaha 
Journal of Business Administration Vol 3, No 2, September 2019, hlm, 194-204

karena dukungan dari pihak perguruan tinggi sangat memberikan pengaruh yang signifikan kepada mahasiwa untuk untuk meningkatkan niat berwirausaha.

Hasil penelitian ini mendukung penelitian dari Suharti (2011) dan Gerry (2008) yang menyatakan bahwa academic support terbukti mempengaruhi niat berwirausaha mahasiswa.

\section{Social Support Berpengaruh Terhadap Niat Berwirausaha Mahasiswa}

Berdasarkan hasil uji statistik pada tabel 2, menunjukkan bahwa variabel social support terbukti berpengaruh terhadap niat berwirausaha mahasiswa. Lingkungan sosial sangat memberikan pengaruh kepada seseorang baik dari dukungan dan motivasi dalam mengambil keputusan. Jika seseorang berada di lingkungan sosial yang mengerti bagaimana dunia usaha maka mereka akan memberikan kontribusi yang tinggi dalam mendorong seseorang untuk berwirausaha.

Hasil penelitian ini mendukung penelitian dari Suharti (2011) dan Abebe (2012) yang menyatakan bahwa academic support terbukti mempengaruhi niat berwirausaha mahasiswa.

\section{Environment Support Berpengaruh Terhadap Niat Berwirausaha Mahasiswa}

Berdasarkan hasil uji statistik pada tabel 2, menunjukkan bahwa variabel environment support terbukti tidak berpengaruh terhadap niat berwirausaha. Dukungan dari lingkungan usaha ternyata tidak memberikan pengaruh besar bagi mahasiswa sebelum memutuskan untuk berwirausaha atau tidak. Prosedur pengurusan dokumen untuk izin usaha di pemerintah yang rumit dan peminjaman modal usaha di bank yang memiliki bunga yang tinggi, membuat mahasiswa tidak memiliki niat untuk berwirausaha.

Kondisi ekonomi yang lemah dari dampak tutupnya sejumlah perusahaan di Batam juga menjadi sebab mahasiswa mengurungkan niat berwirausaha, akibat perusahaan yang tutup melakukan pemutusan hubungan kerja kepada ribuan karyawan, sehingga banyak pengangguran yang tidak memiliki penghasilan membuat daya beli masyarakat berkurang, sehingga kurang menguntungkan bagi mahasiswa untuk memulai berwirausaha pada kondisi ekonomi yang kurang mendukung saat ini.

Hasil penelitian ini mendukung penelitian dari Suharti (2011) dan Rahmadi (2016) yang menyatakan bahwa environment support terbukti tidak mempengaruhi niat berwirausaha mahasiswa.

\section{KESIMPULAN}

Berdasarkan hasil penelitian dan pembahasan yang telah dilakukan, maka dapat disimpulkan bahwa:

1. Tidak terdapat perbedaan niat berwirausaha mahasiswa berdasarkan gender. Hal ini berarti bahwa gender bukan ukuran atau patokan untuk mempengaruhi niat berwirausaha mahasiswa.

2. Pekerjaan orang tua berpengaruh terhadap niat berwirausaha mahasiswa. Hal ini berarti bahwa mahasiswa yang memiliki orang tua berwirausaha akan memiliki niat berwirausaha yang tinggi dibandingkan dengan mahasiswa yang orang tuanya tidak berwirausaha. 
Afriyanti Hasanah \& Nurhasikin, Analisis Faktor-Faktor yang Berpengaruh Terhadap...

3. Pengalaman berwirausaha berpengaruh terhadap niat berwirausaha mahasiswa. Hal ini berarti bahwa mahasiswa yang memiliki pengalaman berwirausaha akan memiliki niat berwirausaha lebih tinggi dibanding mahasiswa yang tidak memiliki pengalaman berwirausaha.

4. Efikasi diri berpengaruh terhadap niat berwirausaha mahasiswa. Hal ini berarti bahwa mahasiswa yang memiliki efikasi diri yang tinggi akan mempengaruhi niat mahasiswa untuk berwirausaha.

5. Pendidikan kewirausahaan berpengaruh terhadap niat berwirausaha mahasiswa. Hal ini berarti bahwa mahasiswa yang telah mendapatkan matakuliah kewirausahaan akan cenderung memiliki niat berwirausaha yang tinggi dibandingkan dengan mahasiswa yang belum mendapatkan matakuliah kewirausahaan.

6. Academic support berpengaruh terhadap niat berwirausaha mahasiswa. Hal ini berarti bahwa mahasiswa yang merasakan dukungan dari pihak akademik untuk berwirausaha akan cenderung memiliki niat berwirausaha yang tinggi dibandingkan dengan mahasiswa yang tidak merasakan dukungan dari pihak akademik.

7. Social support berpengaruh terhadap niat berwirausaha mahasiswa. Hal ini berarti bahwa mahasiswa yang merasakan dukungan sosial untuk berwirausaha akan memiliki niat berwirausaha yang tinggi dibandingkan dengan mahasiswa yang tidak memiliki dukungan sosial.

8. Environment support tidak berpengaruh terhadap niat berwirausaha mahasiswa. Hal ini berarti bahwa dukungan lingkungan tidak berpengaruh terhadap niat berwiruasaha mahasiswa.

\section{Keterbatasan dan Saran}

Peneliti memiliki beberapa keterbatasan dalam penelitian ini yang nantinya dapat diperbaiki pada penelitian selanjutnya. Adapun keterbatasan dalam penelitian ini adalah (1) Peneliti hanya meneliti niat berwirausaha mahasiswa dari jurusan Manajemen Bisnis. (2) variabel independen dari penelitian ini masih bisa ditambah seperti faktor self realization, economic challenge, motivasi dan toleransi akan resiko.

Saran untuk peneliti selanjutnya yaitu: (1) penelitian selanjutnya sebaiknya menambahkan jumlah sampel penelitian, misalnya menggunakan seluruh populasi mahasiswa Politeknik Negeri Batam yang sudah mendapatkan matakuliah kewirausahaan ataupun bisa mengambil sampel mahasiswa yang sudah dan belum mendapatkan matakuliah kewirausahaan untuk mencari hasil perbandingan antara mahasiswa yang belum belajar dan yang sudah belajar (2) penelitian selanjutnya diharapkan menambah variabel lain seperti faktor self realization, economic challenge, motivasi dan toleransi akan resiko.

\section{REFERENSI}

Alan. (2017, Mei Senin). Selama lima bulan 34 perusahaan di Batam tutup. Ribuan Buruh di $P H K$. Retrieved from TribunBatam.id: http://batam.tribunnews.com/2017/05/ 29/selama-lima-bulan-34-perusahaan-dibatam-tutup-ribuan-buruh-di-phk

Abebe, M. (2012) Social and Institutional Predictors of Enterpreneurial Career 
Journal of Business Administration Vol 3, No 2, September 2019, hlm, 194-204

Intention: Envidence From Hispanic Adults in the U.S

Alma, B. (2001). Kewirausahaan. Bandung: Alfabeta.

Arikunto, S. (2005). Manajemen Penelitian . Jakarta: Rineka Cipta.

Bandura. (1997). Self Efficacy the Exercise of Control. New York: W.H freeman and Company.

Chen, J. L., \& Chua, B. (1998). Antecedents for Entrepreurial Propensity and Intention: Finding from Singapore,Taiwan and Hongkong (Working Paper).National University of Singapore Entrepreneurship Center.

Drenan, J., \& Saleh, A. (2008). Dynamics of Entrepreneurship Intentions of MBA Students: An Asian Developing Country Perspective.

Farouk, A., \& Ikram, A. (2014). The Influence of Individual Factors on the Enterpreneurial Intention. International Journal of Managing Value and Supply Chains .

Gerry.C, S., \& Nogueira.F. (2008). tracking Student Entrepreneurial Potential: Personal Attributes and the Prospensity for Business Star Ups after Graduation in a Portuguese University. International Research Journal Problems and Perspectives in Management.

Ghozali. (2006). Metode Statistika . Jakarta: Erlangga.

Gorman, G., Hanlon, D., \& King, W. (1997). Some Research Prespectives on Entrepreneurship Education and Education for Small Business Management: A Ten Year Literature Review. International Small Business Journal.
Gurbuz, G., \& Aykol, S. (2008). Entrepreneurial Intention of Young Educated Public in Turkey. Journal of Global Strategic Management.

Harahap, F. D. (2017, November Senin). Tingkat pengangguran Kepri capai 69.160 orang. Retrieved from BatamPos.co.id:https://batampos.co.id/2017/ 11/13/

tingkat-pengangguran-kepri-capai-69-160orang/

Irawati, R., \& Wahyu, S. (2014). Faktor-Faktor yang Memotivasi Minat Mahasiswi dalam Berwirausaha di Politeknik Negeri Batam. Jurnal Ekonomi Pendidikan dan Kewirausahaan.

Johnson, B. (1990). Toward A Multidimensional Model of Entrepreneurship: the case of Achievment Motivation and the Entrepreneur. Entrepeneurial Theory Practice.

Kasmir. (2012). Kewirausahaan. Jakarta: Rajawali Persada.

Kourilsky, M., \& Carlson, S. (1997). Entrepreneurship Education for Youth: A Curricular Perspective, in Sexton,D.L \& Sanlow, R.W (Eds),Entrepreneurship 2000. Chicago: Upstart Publishing.

Kruger, N. (1993). The Impact of Prior Entrepreneurial Exposure on Perceptions of New Venture Feasibility and Desirability. Entrepre-neurial Theory Practice.

Lee, S., \& Wong, P. (2004). An Exploratory Study of Technopreneurial Intentions A Career Anchor Perspective. Journal of Business Venturing. 
Afriyanti Hasanah \& Nurhasikin, Analisis Faktor-Faktor yang Berpengaruh Terhadap...

Nishanta, B. (2008). Influence of Personality Traits and Socio-demographic Background of Undergraduate Students on Motivation for Entrepreneurial Career : The Case of Srilanka . Paper was Presented at the EuroAsia Management Studies Association (EAMSA) Conference,Japan.

Ormrod, \& Jeanne, E. (2008). Psikologi Pendidikan : Membantu Siswa Tumbuh dan Berkembang. Jakarta: Erlangga.

Priyanto, S. (2008). Di Dalam Jiwa ada Jiwa : The Bacbone and the Social Construction of Entrepreneurship . Pidato Pengukuhan Guru Besar Universitas Kristen Satya Wacana.

Rachmawan, A., Lizar, A. A., \& Mangundjaya, W. L. (2015). The Role Of Parent's Influence and Self Efficacy On Entrepreneurial Intention. The Journal of Developing Areas.

Rahmadi, A. N., \& Haryanto, B. (2016). Analisis Faktor-Faktor yang Mempengaruhi Minat Berwirausaha Pada Mahasiswa Program Studi Manajemen Fakultas Ekonomi Universitas Kediri . Jurnal Ekonomi Kediri.

Robinson, P., Stimpson V, D., Heufner C, J., \& H, H. K. (1991). An Attitude Approach to the Prediction of Entrepreneurship. Baylor University.

Stewart, W., Watson, W., Carland, J., \& Carland, J. (1998). A Proclivity for Entrepreneurship: A Comparison of Entrepreneurs,Small Business Owners and Corporate Managers. Jornal of Business Venturing.

Subanar, H. (2001). Manajemen Usaha Kecil. Yogyakarta.

Sugiyono. (2012). Metode Penelitian Bisnis. Bandung: Alfabeta.
Suharti, L., \& Sirine, H. (2011). Faktor-Faktor yang Berpengaruh Terhadap Niat Kewirausahaan. Jurnal Manajemen dan Kewirausahaan.

Suryana. (2011). Kewirausahaan. Jakarta: Salemba Empat.

Tjahjono, H., \& Ardi, H. (2008). Kajin Niat mahasiswa Manajemen Universitas Muhammadiyah Yogyakarta untuk Menjadi Wirausaha. Utilitas Jurnal Manajemen dan Bisnis.

Vasper, K., \& McMullan, W. (1988). Entrepreneurship: Today Courses,Tomorrow Degrees?.Entrepreneurship Theory and Practice.

Yunita, W. N. (2014). Pengaruh Pendidikan Kewirausahaan Terhadap Motivasi Berwirausaha dan Keterampilan Berwirausaha Mahasiswa Pendidikan Ekonomi UNY.

Sinarasri, A \& Hanum, A. (2016). Pengaruh Latar Belakang Pendidikan Terhadap Motivasi Kewirausahaan Mahasiswa.

Zimmerer, W. (2002). Essentials of Entrepreneurship and Small Business Management. Third Edition. New York: Prentice-Hall.

Zimmerman, B. (2000). Self Efficacy: An Essential Motive to Learn. Annual Edition. Educational Psychology.

Zulianto, M., Santoso, S., \& Sawiji, H. (2014). Pengaruh Efikasi Diri dan Pendidikan Kewirausahaan Terhadap Minat Berwirausaha Mahasiswa Pendidikan Tata Niaga Fakultas Ekonomi. Jurnal Pendidikan Insan Mandiri 